International Journal of Research and Applied Technology

2(1)(2022) 11-29

Journal homepage: https://ojs.unikom.ac.id/index.php/injuratech

\title{
The Effect of Digital Technology and Agility On Company Performance with Management Accounting System as Mediation
}

\author{
W A Astuti*, Y Augustine \\ Accounting Department Faculty of Economic, University of Trisakti, Indonesia \\ Email : *watiaa19@gmail.com
}

\begin{abstract}
The aim of this research was to look into and evaluate the impact of digital technology and agility with management accounting information systems as a mediating variable. The research method used is descriptive analysis and verification. By distributing questionnaires addressed to directors / managers / heads of company divisions. The results showed that digital technology and agility mediated Accounting information systems used by management have a positive impact on organization success. Based on the structural model's assessment, digital technology and accounting information system for management agility have a better strong outcome than the direct effect with a value of $85 \%$. accounting information system for management are required to get over uncertainty in deciding and evaluating the causal relationship that occurs due to digital technology that continues to develop in the millennial era with the agility that companies need. The contribution of research so that companies continue to innovate with changing technological developments and a manager's agility is crucial in decision making.
\end{abstract}

\section{INTRODUCTION}

To survive, the company must improve Its performance, where performance is the product of an employee's work in terms of quality and quantity in carrying out his duties in accordance with the responsibilities assigned to him [1]. Performance is the outcome of a procedure that applies to and is calculated over a period of time based on previously determined provisions or agreements [2]. One of them is by increasing Employee welfare is critical because human resources play a key role in the company's system and development [3], mining companies in Sweden [4] and Australia [5] are engaging in corporate social responsibility activities, diversifying goods for coal companies in China [6], and using a specially developed client application model to manage results. 
Adopting a renewable energy system to increase the short- and long-term financial performance of companies in Romania [7], as well as in many other countries [8], conducting the climate preservation of maintenance China's practices include recycling hazardous substances and reducing corporate emissions [9], limiting exploring commodity and geographic diversification in improving the efficiency of Spanish companies during the crisis economics [10], and debt on photovoltaic companies in China [11], assesses Customer satisfaction with goods, as well as the quality of service [12], demographic traits, commitment, and happiness [13], Hotel efficiency attributes [14] and quality control systems and the quality control scheme. Business efficiency and customer satisfaction are essential factors for enhancing company performance, according to the report. The organization uses the results of customer satisfaction surveys to make continuous changes and modifications to company efficiency. One of them is the use of technology, which is critical in the company [15].

Technology is a tool that is used to make work done easily and quickly. Technology itself always develops from time to time from simple technology to continue to evolve into complex technology. This has created a difficult situation in the workplace: multiple new technological opportunities are perceived, but workers are unsure how to use and integrate them in product and service offerings [16]. Digital technology has entered into various companies, because one of the benefits of incorporating digitalization into different business processes and procedures [17].

Digitalization (the process of transforming analog data into digital data sets) is a digitalization system that is defined as the use of digital resources. The process of digital transformation is then described as a system-wide reorganization of the economy, institutions, and society [18]. Although the above entails transition at all levels of society, digitization opens up unforeseen possibilities and provides the ability to produce fundamentally new products, services, and luxury goods by integrating various innovations (e.g. cloud technology, sensors, big data, 3D printing) [19]. This innovation can result in new ways of collaboration between businesses or changes in customer and employee relationships [20]. Companies can achieve success in terms of efficient resource use by using these emerging embedded digital technologies. cost savings, increased employee productivity and performance, improved supply chain, and increased customer loyalty and satisfaction are just a few of the benefits [21].

During the Covid-19 pandemic, digital technology company Google released the Covid19 Community Mobility Report which can be accessed online and updated regularly. This report helps map the percentage of citizen mobility based on observations of the images and technology used in Google Maps products. In the report on May 13, 2020, it was concluded that in Indonesia there was a decrease in mobility in the public transportation sector, minus 54 percent below the baseline, the retail and recreation sectors such as activities in cafes, recreation areas, restaurants, were recorded at minus 37 percent below baseline, while in the office sector minus 34 percent is below the product, even though there is a record of instability in the mobility chart due to confusion over government policies requiring citizens to work at home.

In the case of Bank Mandiri, digital technology succeeded in protecting customer funds when hardware malfunctions occurred on July 20, 2019. The incident caused changes in the account data of 1.5 million customers from a total of 20 million customers owned by the stateowned bank. As many as 2,670 customer accounts were blocked because they were recorded as having received additional balances and had transferred them to other accounts. And the bank stated that there was no reduction in balances related to disruption of the payment 
International Journal of Research and Applied Technology

2(1)(2022) 11-29

Journal homepage: https://ojs.unikom.ac.id/index.php/injuratech

system and had normalized account balances that were affected by the maintenance of the information technology system [22].

Legal Observer Untan Turiman Fachturaman Nur said the current burglary of customer accounts has increasingly slashed public confidence in the banking world. How could we not, so far we have often been lulled by banking promotions regarding the greatness and reliability of technology. Likewise, systems and standard procedures are relatively better in terms of security. However, along with this we are also presented with the many cases of fraud and fraud committed by internal banking personnel themselves [23].

Strategies due to rapid changes and developments are currently needed in order to respond to rapid changes in consumer or customer demand [24]. Tight competition among companies in certain environments, raising international standards and both controlling prices so much, brings competitive consequences for companies, one of which is the agility or company agility [25].

Agility is an inevitable need in the era of digitalization which is so dynamic and fast in responding to changes in order, accelerating reform of the bureaucracy, structure, integrated regulation, streamlining of flow, to streamlining echelonization. Strategic agility is the capacity to continue to adjust and strategic direction in the core business to create value for the organization, which is Similar to flexibility, which is defined as the ability to remain flexible in the face of new developments, organizational agility is defined as the ability to remain flexible in the face of new developments [26]. Mckinsey defines agility as an organization's ability to renew itself, adapt, and prosper in a rapidly changing world. Agility, on the other hand, does not interfere with stability. Agility is needed for stability for most companies to obtain the necessary information [27].

Based on the survey, only $27 \%$ of respondents thought the company was agile. and culture is considered one of the biggest barriers to adapting to higher levels of agility, with $50 \%$ of respondents calling it a challenge. A deep-rooted culture of company practices and processes can prevent employees from offering new ideas and challenging the status quo [28].

Information is a valuable source of performance driving that allows companies to take action according to company goals by following up on implementation and helping solve problems. Information has the ability to boost an organization's productivity [29].

Digital technology is currently increasingly important which will have an impact on the management accounting system [30], which has led to in the past few years, there have been some significant changes in accounting procedure [31]. Accountants today must not only assume a new position in their organizations' management, but they must also be aware of the new practices and procedures dictated by evolving information technology and systems, as well as their effect on management accounting information systems [32].

Management Accounting Systems are expected to prepare managers in forming the right format for managers with equal satisfaction with information needs Managers who use information have prepared a Management Accounting System to be able to help organizations adopt and implement plans in response to their competitive environment [33,34].

The management accounting information system is an organizational monitoring mechanism that can facilitate supervision by making reports and creating concrete actions for evaluating the performance of each component in the organization, with the increase in problem solving tasks faced by management, the design of management accounting information systems is not only oriented to financial data but is oriented to external and nonfinancial data. The function of the management accounting system provides an important 
source of information to assist managers in controlling their activities and reducing uncertainty, so that they can help the company achieve its goals [35].

The phenomenon that arises regarding the lack of quality management accounting information systems and unqualified management accounting information systems occurs in the banking industry. Trust in banking is not only related to the security of customer deposits at the bank, but also to the security of systems and procedures, the use of technology and human resources in providing services to customers. One aspect of risk that has not been widely anticipated until now is the failure of banking transactions through information technology (technology fraud), which is categorized as operational risk. In the case of PT Bank Century Tbk, it was deemed to have the potential to trigger a systemic crisis, following a clearing error that was experienced by the bank's internal problems which indicated that the central bank did not provide transparent, accurate and timely information to the Financial System Stability Committee (KSSK) and the Deposit Insurance Corporation. In addition, the information regarding the CAR (Capital Adequacy Ratio) of Century Bank was not actual, so the decisions made regarding the amount of funds for the bailout differed, from IDR. 689 billion to IDR. 6.7 trillion.

In order to face the ASEAN Economic Community (AEC) in the banking sector in 2020, the Financial Services Authority (OJK) as the regulator views that the national banking industry still has a lot of homework to do in order to be able to compete with other banks from the Southeast Asian region [36].

This study develops the research described above. The important things that distinguish this research from previous research are as follows: 1) The effect of digital technology on the availability of broad scope information has been carried out, but previous research has not linked these two variables to company performance. 2) Agility variables associated with company performance and management accounting information systems in this study are not only related to scope, timeliness; aggregation level, and level of integration.

\subsection{Agency Theory}

In the financial literature, agency theory plays an important role in explaining the relationship between principals and agents in carrying out their respective functions and authorities. Agency conflicts often arise due to information asymmetry due to differences in interests between the principal and the agent, which will lead to problems between the various parties involved. Managers would eventually have considerable power rights in terms of how they divide investor funds due to the division of positions between shareholders as principals and managers as agents [37].

\subsection{Digital Technology}

Digital transformation is driving change in the business world, because they build new internet-based technologies that have ramifications for the whole community [38]. Digitization, on the other hand, is the method of transforming analogue and noisy data into digital data, digitization is a word that is used to describe any improvements in organizations and organizational $\mathrm{BM}$ as a result of the increased usage of digital technologies to enhance efficiency and expand business reach [39, 40], in the third step. Defines Unruh and Kiron define digital transformation as the continuous interconnection of all market sectors and the adaptation of the actor's side to the needs of the digital economy, while Unruh and Kiron define it as the adaptation of the actor's side to the needs of the digital economy (2017). Define 
International Journal of Research and Applied Technology

2(1)(2022) 11-29

Journal homepage: https://ojs.unikom.ac.id/index.php/injuratech

it as a restructuring of the level of the economic system, Digital diffusion affects both institutions and culture. This form of digitization is progressing from a technological evolution to a phenomenon that can affect all forms of businesses. Manufacturing companies should also go digital (for example, Industry 4.0) because the physical and digital worlds are constantly colliding and need to work together [41]. This can be accomplished, for example, by incorporating the Internet of Things and Services into manufacturing processes and extracting value through the analysis and management of data that can be used as a source of competitive advantage $[42,43]$. As a result, many of the changes brought on by digitization threaten and turn existing divisions Companies that formerly dominated the market are now up against new rivals that are redefining an old industry. Meanwhile, customers have broad access to information through the internet and a variety of channels from which to choose.

\subsection{Agility}

Agility refers to the ability to move quickly and easily and think quickly with a thoughtful method. The roots or origins of agility come from agile production and this is a concept that has been presented for several years. Agile production has been accepted as a successful strategy by manufacturers which prepares them for extraordinary performance [44]. WymanOliver defines organizational agility as' the capacity of a company to be able to adapt indefinitely without having to make radical changes, a measure of agility on sensing agility the agility of decision makers [45, 46].

\subsection{Company Performance}

The dominant performance of the company used by previous researchers is the achievement of financial and non-financial factors. Financial performance, if supported by non-financial aspects, will be more representative of the company's performance [47]. The final goal will be achieved, not only supported by financial factors, non-financial factors are also needed, such as processes that also play a role in achieving company goals. These two indicators can illustrate a broader perspective in measuring performance. Today organizations focus on managing intangible assets (e.g., customer relationships, innovative products and services, high quality and responsive operating processes) of a non-financial nature, rather than managing tangible assets (such as fixed assets and inventories) [48].

\subsection{Management Accounting Information System}

The management accounting system is a data collection, processing, storage, and reporting system for organizational and financial data. Products produced by the management accounting system [49], present one of the most widely cited approaches to accessing MAS characteristics, which includes scope, timeliness, aggregation and integration. In several studies, the information dimension is used as the dependent variable [50].

\subsection{Hypothesis Development}

Companies with superior IT capabilities outperform companies with inferior IT capabilities, according to [51]. Similarly, Chen et al. discovered a significant relationship between IT and company results [52]. Found that digital orientation and digital capabilities have a positive effect on company performance. This research demonstrates that the characteristics of entrepreneurs and managers, as well as their embrace of modern digital processes, contribute 
International Journal of Research and Applied Technology

2(1)(2022) 11-29

Journal homepage: https://ojs.unikom.ac.id/index.php/injuratech

to increased company competitiveness. So based on the explanation above in this study it is hypothesized that:

H1: Digital technology has an effect on company performance

Gligor said that whether supply chain agility can also produce superior performance for companies operating in a stable environment [53]. The study results also provide a better understanding of how FSCA contributes to a company's financial performance. Said that low market volatility strengthens the impact of innovation capacity on financial results, and that market volatility moderates the indirect relationship between marketing agility and financial performance. [54], in his research, concluded that IT capabilities act in the capacity of a company enabler processes and organizations that are responsive to market agility. So based on the explanation above in this study it is hypothesized that:

\section{H2: Agility affects company performance}

Managers sometimes do not realize the decline in company performance, so that the company has entered into a crisis zone that is considered serious. Therefore, it takes strategies by managers to avoid this condition. One of these strategies is the existence of an information system that is orderly and as best integrated as possible. This data is unquestionably beneficial to managers in their planning, reporting, and decision-making processes. This data is SAM information [55].

Research conducted by Chia regarding the relationship between decentralization, the Management accounting information system characteristics and their effect on managerial efficiency shows that decentralization is significantly able to bridge the level of progress of each characteristic of management accounting systems in influencing organizational performance [56]. The sample was chosen at random from The Telecommunications Authority of Singapore's Business Listing 1990. In the end, 48 questionnaires were used in the study's review. So centered on the preceding explanation in this study it is hypothesized that:

\section{H3: Management Accounting Information System Affects Company Performance}

Digital technology affects management accounting information systems. In management accounting systems research based on the assumption of industrial evolution in digital settings, it requires assessing the stability of business model relationships in a rapidly growing digital economy [57], in studying organizations with sustainable information systems a process structure from a digital context [58]. The technology has an effect on management accounting information systems. So centered on the preceding explanation in this study it is hypothesized that:

H4: Digital technology affects management accounting information systems

According to Ekweli findings, there is a significant link between product creativity and organizational agility in the Nigerian banking sector [59]. As a result, product innovation to join the Nigerian banking sector resulted in high sensing agility, decision-making agility, and action agility, supporting the view of long-term management innovation and organizational maturity, where agility is one of the various methods and techniques for improving organizational efficiency. In general, in reality, achieving agility is part of a broader crossorganizational initiative to introduce fundamental changes or advancements to structures and sub-systems. As a result, the assistance is in the form of structural change, which includes: (a) A focus on quality improvement in the strategy-action-performance cycle, and (b) an 
International Journal of Research and Applied Technology

2(1)(2022) 11-29

Journal homepage: https://ojs.unikom.ac.id/index.php/injuratech

understanding of the value of aligning IT, human resource management, and related operations. So based on the explanation above in this study it is hypothesized that:

H5: Agility affects management accounting information systems

Digital technology can improve monitoring and reduce the specification of existing relationships in explicit coordination, so that companies will invest in digital technology to coordinate between companies without worrying about high transaction risks. Management accounting information systems play a critical role in performance assessment, providing data that is often used to determine the metrics that will allow an efficient performance measurement process. This procedure encompasses every part of a company's management cycle. Throughout the literature review, several studies evaluating different types of performance were found, including the following performance dimensions: production performance [60]. So based on the explanation above in this study it is hypothesized that:

H6: Digital Technology has an indirect effect on Company Performance by mediating Management Accounting Information Systems

Found that the results of the study showed a strategic partial relationship to the agility variable through Path Analysis. Stated that a significant relationship was found between firm age and strategic agility, and between strategic agility and firm performance. Pedroso said the results show that MAS is directly affected by user Task confusion and decision decentralization, as well as preparation and satisfaction. It is also affected indirectly by the assistance of top management [61]. Furthermore, it is discovered that decentralization of managerial decisions has a direct impact on organizational success [62], Management accounting information systems do not mediate the relationship between innovation strategies and financial performance, according to the findings of the report. The relationship between innovation strategy and financial performance is mediated by internal process performance. The relationship between innovation strategy and financial performance is mediated by management accounting information systems and internal process performance. So based on the explanation above in this study it is hypothesized that:

H7: Agility affects Company Performance through Management Accounting Information Systems mediation

\section{Method}

\subsection{Sampling and data collection}

The objects in this research are digital technology, agility, management accounting information systems and company performance. The unit of analysis by Sekaran et al, in their study at BUMN Bank in Bandung, the authors chose the city of Bandung, because Bandung has certain characteristics as an object, or research target in saving costs and time [63, 64]. The population is all the objects under study, the sample used in this analysis is a saturated sample, in which the population is equal to the number of samples taken for a particular purpose or purpose, since saturated sampling makes it easier to collect data, more practical, inexpensive and does not require time to collect sample data [65]. Data is gathered mainly through the distribution of questionnaires, then the data is tested for validity by validity testing, namely testing how well the instrument is selected and can be developed in measuring a concept and reliability, namely a test to measure how consistency is related. 
International Journal of Research and Applied Technology

2(1)(2022) 11-29

Journal homepage: https://ojs.unikom.ac.id/index.php/injuratech

\section{Results and Discussion}

\subsection{Data analysis}

Path analysis is the data analysis approach used in this research. Path analysis is a technique for determining the magnitude of the direct or indirect influence of a series of independent variables on a dependent variable by examining the pattern of relationships between variables [66]. Path analysis is also a method of multivariate analysis used to investigate the direct and indirect effects of a variety of variables hypothesized as causal variables on other variables known as impact variables. The causal relationship a model based on theoretical foundation has been used to form relationships between variables. The SPSS software will be used to analyze the data in this analysis [67]. The path coefficient of model 1, refers to regression model 1 the significance value of the independent variable is less than 0.05 , as seen in the coefficient table section. Based on these findings, regression model 1 is the best choice. The independent variable, in particular, has a major influence on the dependent variable. The $R$ square represents the contribution of the independent variable's impact on the dependent variable.

$\mathrm{SIAM}=\beta \mathrm{DT}+\beta \mathrm{AG}+\varepsilon$

Path coefficient model 2, refers to regression model 2 the significance value of the independent variable is less than 0.05 , as seen in the coefficient table section. Based on these findings, regression model 2, i.e. the independent variable, has a substantial impact on the dependent variable. The $\mathrm{R}$ square represents the contribution of the independent variable's impact on the dependent variable.

$\mathrm{KP}=\beta \mathrm{DT}+\beta \mathrm{AG}+\beta \mathrm{SIAM}+\varepsilon$

Information: SIAM = Management Accountancy Information System, $\mathrm{KP}=$ Company Performance, $\mathrm{DT}=$ Digital Technology, $\mathrm{AG}=$ Agility,$\varepsilon=$ error

\subsection{Results}

This segment delves into the study and findings of studies on the impact of digital technology. agility as a variable that is independent on company performance in the position of dependent variable with management accounting information systems as a mediating variable. This research relies on primary data by distributing questionnaires in the shape of Google Form. The characteristics of the 150 respondents were classified based on the gender of the respondent, 78 men $(52 \%)$ and 72 women (48\%), the respondent's education, 149 people from tertiary education (99\%) and 1 high school (1\%), this means Most of the respondents were highly educated and able to understand the questions in the questionnaire and were competent in providing answers. Judging from the average age of the respondents above 25 years, this shows that the respondents are mature and mature in their work and the average length of work of the respondents is above 5 years, this shows that the respondents are experienced in their work.

\subsection{Descriptive Statistics}


International Journal of Research and Applied Technology

$$
\text { 2(1)(2022) 11-29 }
$$

Journal homepage: https://ojs.unikom.ac.id/index.php/injuratech

Descriptive statistics or analysis is very important to do in a study because descriptive statistics have a useful purpose to analyze the responses of respondents to each indicator item in the questionnaire.

Table 1. Descriptive Statistic

\begin{tabular}{|c|c|c|c|c|c|c|c|c|}
\hline & $\begin{array}{c}\mathbf{N} \\
\text { Statistic }\end{array}$ & $\begin{array}{c}\text { Range } \\
\text { Statistic }\end{array}$ & $\begin{array}{c}\text { Min. } \\
\text { Statistic }\end{array}$ & $\begin{array}{c}\text { Max. } \\
\text { Statistic }\end{array}$ & $\begin{array}{l}\text { Mean } \\
\text { Stac. }\end{array}$ & Std.Eror & $\begin{array}{c}\text { St.Dev } \\
\text { Statistic }\end{array}$ & Category \\
\hline Digital Technology & 150 & 64 & 43 & 107 & 61.81 & 1.056 & 9.441 & High \\
\hline Agility & 150 & 21 & 24 & 45 & 36.71 & .594 & 5.311 & High \\
\hline $\begin{array}{l}\text { Management Accountancy } \\
\text { Information System }\end{array}$ & 150 & 24 & 36 & 60 & 48.65 & .760 & 6.801 & High \\
\hline $\begin{array}{l}\text { Company Performance } \\
\text { Valid N }\end{array}$ & $\begin{array}{l}150 \\
150\end{array}$ & 45 & 55 & 100 & 82.54 & 1.150 & 10.288 & High \\
\hline
\end{tabular}

On the basis of Table 1, it can be deduced that descriptive statistics with a sample size of 150 respondents, digital technology variables show the results of descriptive statistical analysis with a minimum quantity of 0.43 , a maximum quantity of 0.107 , the average value showing positive results of 61.81 and a standard deviation value of 9,441 . Where the average value of digital technology is greater than the standard deviation value, resulting in a lower data deviation, the distribution of values is even. The results of descriptive statistical analysis show that the minimum agility worth is 0.24 , the maximum worth is 0.45 , the typical value shows a positive result of 36.71 and a standard deviation value of 5.311. Where the average agility value is greater than the standard deviation value, resulting in a lower data deviation, the distribution of values is even. The results of descriptive statistical analysis show that the minimum value of the management accounting information system is 0.36 , the maximum value is 0.60 , the average value is 48.65 and the standard deviation is 6.801 . Where the average value of the accounting information system is greater than the standard deviation value, so the data deviation that occurs is lower, the distribution of values is even. The results of descriptive statistical analysis show that the minimum value of company performance is 0.55 , the highest possible value is 0.10 , the typical value is 82.54 and the variance from the mean is 10.288 . Where the average value of the company's performance is greater than the standard deviation value so that the data deviation that occurs is lower, then the distribution of values is even.

Furthermore, it can be seen that the average respondent's assessment of the digital variable technology, agility, management accounting information systems and overall company performance is included in the high category. This shows that some of the companies studied in Bandung have digital technology, agility, management accounting information systems and good company performance in following developments in digitalization era technology with agility in making decisions and fast information systems in improving company performance.

\subsection{Data Quality Test}

Validity checking is done using item analysis, which involves comparing the score of each item to the variable score (the sum of all the score item questions). Pearson Correlation is used in the correlation process. The question item is declared valid if it has a significant value below $5 \%$ (0.05). The results of the validity test in this study there were no question items that had a 
International Journal of Research and Applied Technology

$$
\text { 2(1)(2022) 11-29 }
$$

Journal homepage: https://ojs.unikom.ac.id/index.php/injuratech

significance value above 0.05 , so that the items were declared valid and could be used in the study.

Reliability testing in this study was calculated by calculating the value of the Cron-Bach's Alphainstrumen from each dimension of the variable being tested. If the Cronbach's Coefficient Alpha value is greater than 0.6, then the answers from the respondents to the questionnaire as a measuring tool are declared reliable. If the Cronbach's Coefficien $t$ Alpha value is smaller than 0.6, then the answers of the respondents on the questionnaire as a measuring tool are declared unreliable. Table 2 shows the results of the reliability tests.

Table 2. Validity and Reliability Test

\begin{tabular}{|c|c|c|c|c|c|c|}
\hline \multirow{2}{*}{$\begin{array}{l}\text { variable / } \\
\text { statement }\end{array}$} & & \multirow[b]{2}{*}{$r$ calculate } & \multicolumn{3}{|c|}{ Validity } & \multirow{2}{*}{$\begin{array}{c}\text { Reliability } \\
\text { Cronbach } \alpha>r \\
\text { tabel }\end{array}$} \\
\hline & & & $r$ table & r hitung $>$ r tabel & Cronbach $a$ & \\
\hline $\begin{array}{l}\text { Company } \\
\text { Performance }\end{array}$ & $\begin{array}{c}1 \\
2 \\
3 \\
4 \\
5 \\
6 \\
6 \\
7 \\
8 \\
9 \\
10 \\
11 \\
12 \\
13 \\
14 \\
15 \\
16 \\
17 \\
18 \\
19 \\
20\end{array}$ & $\begin{array}{l}.711 \\
.771 \\
.659 \\
.765 \\
.695 \\
.826 \\
.766 \\
.722 \\
.594 \\
.838 \\
.832 \\
.753 \\
.758 \\
.865 \\
.850 \\
.801 \\
.712 \\
.781 \\
.837 \\
756\end{array}$ & $\begin{array}{l}0.286 \\
0.286 \\
0.286 \\
0.286 \\
0.286 \\
0.286 \\
0.286 \\
0.286 \\
0.286 \\
0.286 \\
0.286 \\
0.286 \\
0.286 \\
0.286 \\
0.286 \\
0.286 \\
0.286 \\
0.286 \\
0.286 \\
0.286\end{array}$ & $\begin{array}{l}\text { Valid } \\
\text { Valid } \\
\text { Valid } \\
\text { Valid } \\
\text { Valid } \\
\text { Valid } \\
\text { Valid } \\
\text { Valid } \\
\text { Valid } \\
\text { Valid } \\
\text { Valid } \\
\text { Valid } \\
\text { Valid } \\
\text { Valid } \\
\text { Valid } \\
\text { Valid } \\
\text { Valid } \\
\text { Valid } \\
\text { Valid } \\
\text { Valid }\end{array}$ & .765 & Reliability \\
\hline $\begin{array}{l}\text { Digital } \\
\text { Technology }\end{array}$ & $\begin{array}{c}1 \\
2 \\
3 \\
4 \\
5 \\
6 \\
7 \\
8 \\
9 \\
10 \\
11 \\
12 \\
13 \\
\end{array}$ & $\begin{array}{l}.552 \\
.565 \\
.519 \\
.503 \\
.438 \\
.402 \\
.504 \\
.604 \\
.579 \\
.667 \\
.590 \\
.451 \\
.565\end{array}$ & $\begin{array}{l}0.286 \\
0.286 \\
0.286 \\
0.286 \\
0.286 \\
0.286 \\
0.286 \\
0.286 \\
0.286 \\
0.286 \\
0.286 \\
0.286 \\
0.286 \\
\end{array}$ & $\begin{array}{l}\text { Valid } \\
\text { Valid } \\
\text { Valid } \\
\text { Valid } \\
\text { Valid } \\
\text { Valid } \\
\text { Valid } \\
\text { Valid } \\
\text { Valid } \\
\text { Valid } \\
\text { Valid } \\
\text { Valid } \\
\text { Valid }\end{array}$ & .676 & Reliability \\
\hline
\end{tabular}


International Journal of Research and Applied Technology

$$
\text { 2(1)(2022) 11-29 }
$$

Journal homepage: https://ojs.unikom.ac.id/index.php/injuratech

\begin{tabular}{|c|c|c|c|c|c|c|}
\hline \multirow{2}{*}{$\begin{array}{l}\text { variable } \\
\text { statemen }\end{array}$} & & \multirow[b]{2}{*}{$r$ calculate } & \multicolumn{3}{|c|}{ Validity } & \multirow{2}{*}{$\begin{array}{c}\text { Reliability } \\
\text { Cronbach } \alpha>\text { r } \\
\text { tabel }\end{array}$} \\
\hline & & & $r$ table & $r$ hitung $>r$ tabel & Cronbach $\underset{\alpha}{\alpha}$ & \\
\hline & 14 & .585 & 0.286 & Valid & \multirow{11}{*}{.784} & \multirow{11}{*}{ Reliability } \\
\hline & 15 & .607 & 0.286 & Valid & & \\
\hline \multirow{9}{*}{ Agility } & 1 & .711 & & & & \\
\hline & 2 & .796 & 0.286 & Valid & & \\
\hline & 3 & .760 & $\begin{array}{l}0.286 \\
0286\end{array}$ & $\begin{array}{l}\text { Valid } \\
\text { Valid }\end{array}$ & & \\
\hline & 4 & .834 & 0.286 & $\begin{array}{l}\text { Valid } \\
\text { Valid }\end{array}$ & & \\
\hline & 5 & .831 & 0.286 & Valid & & \\
\hline & 6 & .751 & 0.286 & Valid & & \\
\hline & 7 & .826 & 0.286 & Valld & & \\
\hline & 8 & .755 & $\begin{array}{l}0.286 \\
0286\end{array}$ & $\begin{array}{l}\text { Valid } \\
\text { Valid }\end{array}$ & & \\
\hline & 9 & .775 & $\begin{array}{l}0.280 \\
0.286\end{array}$ & $\begin{array}{l}\text { Valld } \\
\text { Valid }\end{array}$ & & \\
\hline & 1 & .825 & 0.286 & Valid & \multirow{12}{*}{.779} & \multirow{12}{*}{ Reliability } \\
\hline & 2 & .804 & 0.286 & Valid & & \\
\hline & 3 & .761 & 0.286 & Valid & & \\
\hline & 4 & .832 & 0.286 & Valid & & \\
\hline Management & 5 & .764 & 0.286 & Valid & & \\
\hline Accountancy & 6 & .870 & 0.286 & Valid & & \\
\hline Information & 7 & .827 & 0.286 & Valid & & \\
\hline \multirow[t]{5}{*}{ System } & 8 & .794 & 0.286 & Valid & & \\
\hline & 9 & .816 & 0.286 & Valid & & \\
\hline & 10 & .861 & 0.286 & Valid & & \\
\hline & 11 & .873 & 0.286 & Valid & & \\
\hline & 12 & .848 & 0.286 & Valid & & \\
\hline
\end{tabular}

\subsection{Hypothesis Testing Results}

Table 3. Hypothesis Testing Results

\begin{tabular}{ccccccc}
\hline Hypothesis & $\boldsymbol{\beta}$ & Std.Error & Beta & $\mathbf{T}$ & Sign. & Description \\
\hline $\mathrm{DT} \rightarrow \mathrm{CP}$ & .080 & .063 & .073 & 1.269 & .208 & Ha rejected \\
$\mathrm{AG} \rightarrow \mathrm{CP}$ & .409 & .139 & .211 & 2.943 & .004 & Ha accepted \\
$\mathrm{MAIS} \rightarrow \mathrm{CP}$ & 1.071 & .102 & .708 & 10.498 & .000 & Ha accepted \\
$\mathrm{DT} \rightarrow$ MAIS & .113 & 0.69 & .157 & 2.635 & .106 & Ha rejected \\
$\mathrm{AG} \rightarrow$ MAIS & .830 & .123 & .648 & 6.746 & .000 & Ha accepted \\
$\mathrm{DT} \rightarrow \mathrm{CP} \rightarrow$ MAIS & & $\mathrm{T}_{\text {count }}=2.255$ & $>\mathrm{T}_{\text {table }}=1.199045$ & & Ha accepted \\
$\mathrm{AG} \rightarrow \mathrm{CP} \rightarrow$ MAIS & & $\mathrm{T}_{\text {count }}=4.169>\mathrm{T}_{\text {table }}=1.199045$ & & Ha accepted \\
\hline
\end{tabular}


International Journal of Research and Applied Technology

$$
\text { 2(1)(2022) 11-29 }
$$

Journal homepage: https://ojs.unikom.ac.id/index.php/injuratech

$\mathrm{H} 1, \mathrm{H} 2, \mathrm{H} 3, \mathrm{H} 4$, and $\mathrm{H} 5$ hypotheses are tested using the $\mathrm{t}$ test and for hypotheses 6 and 7 using the $\mathrm{F}$ test as shown in table 3:

H1: Digital technology affects company performance.

By using a significance of 0.05 , the $t$ value obtained at $\mathrm{df}=\mathrm{nk}=(80-4=76)$ is 1.991673 and $t$ count is 6.778, thus the $t$ value of significance is greater than the $t$ table or 6.778>1.991673, This means that digital technology has an important impact on the success of the company. As that the first hypothesis which states that there is a significant impact between digital technology on company performance.

H2: Agility affects company performance.

By using a significance of 0.05 , the $t$ value obtained at $\mathrm{df}=\mathrm{nk}=(80-4=76)$ is 1.991673 and $t$ count is 2.943, thus the $t$ value of significance is greater than the $t$ table or 2.943>1.991673, This means that agility has a significant effect on company performance. So that the second hypothesis which states that there is a significant impact between agility on company performance.

H3: Management accounting information system affects company performance.

By using a significance of 0.05 , the $t$ value at $\mathrm{df}=\mathrm{nk}=(80-4=76)$ is 1.991673 and the $\mathrm{t}$ count is 10.498, thus the $t$ value of significance is greater than the $t$ table or 10.498>1.991673, This indicates that the management accounting information system has a direct impact on the company's overall efficiency. So, the third hypothesis notes that management accounting information systems have a direct impact on organization results.

H4: Digital technology affects management accounting information systems.

By using a significance of 0.05 , the $t$ value obtained at $\mathrm{df}=\mathrm{nk}=(80-4=76)$ is 1.991673 and $t$ count is 2.635, thus the $t$ value of significance is greater than the $t$ table or 2.635> 1.991673, As a result, digital technology has a major influence on accounting and management information systems. As a consequence, according to the fourth theory, new technology has a significant effect on management accounting information systems.

H5: Agility affects management accounting information systems.

By using a significance of 0.05 , the $t$ value obtained at $\mathrm{df}=\mathrm{nk}=(80-4=76)$ is 1.991673 and $t$ count is 6,746, thus the $t$ value of significance is greater than $t$ table or 6,746>1.991673, This suggests that the management accounting information system is affected by agility. So, according to the fifth theory, there is a substantial impact of agility on management accounting information systems.

H6: Indirect effect of digital technology on company performance through management accounting information systems.

By using a significance of 0.05 , the $t$ value obtained at $\mathrm{df}=\mathrm{nk}=(80-4=76)$ is 1.991673 and $t$ count is 2.255 , thus the $t$ value of significance is greater than $t$ table or $2.255>1.991673$, it can 
International Journal of Research and Applied Technology

2(1)(2022) 11-29

Journal homepage: https://ojs.unikom.ac.id/index.php/injuratech

be concluded that the coefficient of management accounting information systems is able to mediate the relationship between digital technology and company performance.

H6: Indirect effect of digital technology on company performance in mediating management accounting information systems.

By using a significance of 0.05 , the $t$ value obtained at $\mathrm{df}=\mathrm{nk}=(80-4=76)$ is 1.991673 and $t$ count is 2.255, thus the $t$ value of significance is greater than $t$ table or 2.255> 1.991673, the coefficient of management accounting information systems, it can be concluded, is capable of mediating the relationship between digital technology and company results. As a result, the sixth hypothesis notes that emerging technology has a major impact on organization efficiency, which is mediated by management accounting information systems.

H7: Indirect effect of agility on company performance as management accounting information system mediation.

By using a significance of 0.05 , the $t$ value obtained at $\mathrm{df}=\mathrm{nk}=(80-4=76)$ is 1.991673 and $t$ count is 4.169, thus the $t$ value of significance is greater than the $t$ table or 4.169>1.991673, The management accounting information system coefficient, it can be inferred, is capable of mediating the relationship between agility and company results. So, according to the seventh hypothesis, there is a major impact of agility on organization results, which is mediated by the management accounting information system.

\subsection{Discussion}

Based on the findings of this study's data analysis and hypothesis testing, it is clear that digital technology has a positive and important impact on business success. This demonstrates that the higher the company's efficiency, the better the digital technology it has introduced. The findings of this hypothesis are in line with research by Kim, who found that digital orientation and digital capabilities have a positive effect on company performance [68]. Using data interpretation and hypothesis testing as a foundation that has been carried out in this study, it shows that agility has a positive and significant impact on company performance. This shows that the better the agility applied by the company, the better the company's performance. The results of this hypothesis are consistent with research conducted, which states that supply chain agility can also produce superior performance for companies operating in a stable environment.

Using data interpretation and hypothesis testing as a foundation that has been done in this study, it shows that the management accounting information system has a positive and significant effect on company performance. This shows that the better the management accounting information system implemented by the company, the better the company's performance. The results of this hypothesis are consistent with research conducted regarding the relationship between decentralization, the characteristics of management accounting information systems and their effect on managerial performance. It shows that decentralization is significantly able to bridge the level of progress of each characteristic of management accounting systems in influencing organizational performance.

Based on data analysis and hypothesis testing that has been done in this study, it shows that digital technology is proven to have a positive effect on management accounting information systems. This shows that the better the digital technology implemented by the company, the better the management accounting information system. The results of this hypothesis are consistent with research by Wadan et al., that the management accounting 
International Journal of Research and Applied Technology

2(1)(2022) 11-29

Journal homepage: https://ojs.unikom.ac.id/index.php/injuratech

system rests on the assumption of industrial evolution in a digital setting requiring an assessment of the stability of business model relationships in a rapidly growing digital economy [69]. Based on the findings of this study's data analysis and hypothesis testing, it appears that management accounting information systems agility has a positive and substantial impact on company results. This shows that the better the agility, the better the management accounting information system implemented by the company. The findings of this hypothesis are in line with Alessandro's research in order to establish a semantic model of organizational agility, in which a static or taxonomic approach to representing components and sub-components is transformed into a dynamic conceptual model of organizational agility.

Based on data analysis and hypothesis testing that has been carried out in this study, it shows that the management accounting information system mediation coefficient is able to mediate the relationship between digital technology and company performance. Thus the increasing application of digital technology also increases the availability of management accounting system information which will provide many alternative solutions that can be considered so that company performance can be improved. The results of this hypothesis are consistent with the research by Ismail which said that companies that have a good management accounting information system will also have good digital technology and the level of managerial performance will be even better [70].

Based on data analysis and hypothesis testing that has been carried out in this study, it shows that the management accounting information system mediation coefficient is able to mediate the relationship between agility and company performance. Thus, the increasing implementation of agility (agility) will also increase the availability of management accounting system information which will provide many alternative solutions that can be considered so that company performance can be improved. stated that a significant relationship was found between firm age and strategic agility, and between strategic agility and firm performance. Said the results show User preparation, satisfaction, job uncertainty, and decision decentralization all have an effect on MAS. It is also affected indirectly by the assistance of top management. Furthermore, it is discovered that decentralization of managerial decisions has a direct impact on organizational success.

\section{Conclusion}

This study aims to test digital technology and agility on company performance by mediating management accounting information systems. From testing and analysis of the data, it can be shown that digital technologies, agility, and management accounting information systems have a huge positive impact on company success. The implications of this research are 1 . For companies, they must continue to innovate with the development of technology which is constantly changing with the agility of a manager which is very decisive in decision making. For investors, it is hoped that investors can use the results of this research as a consideration and reference in making investors' decisions and should consider the level of competition with other companies. For further researchers, it is possible to add research respondents, so that the sample used is more and more representative in the hope that it can give stronger results, conduct research observations in other sectors and for further researchers can add other variables that affect company performance, for example leadership style, organizational structure and others. 4 . for the government to be able to provide regulatory policies on banking. Limitations in this study regarding the relatively short time used and the variables 
International Journal of Research and Applied Technology

$$
\text { 2(1)(2022) 11-29 }
$$

Journal homepage: https://ojs.unikom.ac.id/index.php/injuratech

used are limited to digital technology, agility, company performance and management accounting information systems.

\section{REFERENCES}

[1] Mangkunegara, A.A., Anwar, P. (2016). Manajemen Sumber Daya Manusia Peusahaan, PT. Remaja Rosdakarya.

[2] Emron, E., Anwar, Y., \& Komariah, I. (2016). Manajemen Sumber. Daya Manusia. Bandung: Alfabeta.

[3] Scafà, M., Papetti, A., Brunzini, A., \& Germani, M. (2019). How to improve worker's wellbeing and company performance: A method to identify effective corrective actions. Procedia CIRP, 81, 162-167.

[4] Larsen, R. K., Österlin, C., \& Guia, L. (2018). Do voluntary corporate actions improve cumulative effects assessment? Mining companies' performance on Sami lands. Extractive Industries and Society, 5(3), 375-383.

[5] Phillips, S., Thai, V. V., \& Halim, Z. (2019). Airline Value Chain Capabilities and CSR Performance: The Connection Between CSR Leadership and CSR Culture with CSR Performance, Customer Satisfaction and Financial Performance. Asian Journal of Shipping and Logistics, 35(1), 30-40.

[6] Li, C. M., Cui, T., Nie, R., Lin, H., \& Shan, Y. (2019). Does diversification help improve the performance of coal companies? Evidence from China's listed coal companies. Resources Policy, 61(February 2018), 88-98.

[7] Dumitrache, C., Kherbash, O., \& Mocan, M. L. (2016). Improving Key Performance Indicators in Romanian Large Transport Companies. Procedia - Social and Behavioral Sciences, 221, 211-217.

[8] Martí-Ballester, C. P. (2017). Sustainable energy systems and company performance: Does the implementation of sustainable energy systems improve companies' financial performance? Journal of Cleaner Production, 162, S35-S50.

[9] Song, H., Zhao, C., \& Zeng, J. (2017). Can environmental management improve financial performance: An empirical study of A-shares listed companies in China. Journal of Cleaner Production, 141, 1051-1056.

[10] Xu, L., Zhang, Q., Wang, K., \& Shi, X. (2020). Subsidies, loans, and companies' performance: evidence from China's photovoltaic industry. Applied Energy, 260(August 2019).

[11] Garrido-Prada, P., Delgado-Rodriguez, M. J., \& Romero-Jordán, D. (2019). Effect of product and geographic diversification on company performance: Evidence during an economic crisis. European Management Journal, 37(3), 269-286.

[12] Blessing, G., Natter, M. (2019). Do Mystery Shoppers Really Predict Customer Satisfaction and Sales Performance? Journal of Retailing, 95(3), 47-62.

[13] Khin, S., \& Ho, T. C. F. (2019). Digital technology, digital capability and organizational performance: A mediating role of digital innovation. International Journal of Innovation Science, 11(2), 177-195.

[14] Ahani, A., Nilashi, M., Yadegaridehkordi, E., Sanzogni, L., Tarik, A. R., Knox, K., Samad, S., \& Ibrahim, O. (2019). Revealing customers' satisfaction and preferences through online review analysis: The case of Canary Islands hotels. Journal of Retailing and Consumer Services, 51(June), 331-343.

[15] Bivisyani Questibrilia. (2019). Human Resource. 
International Journal of Research and Applied Technology

$$
\text { 2(1)(2022) 11-29 }
$$

Journal homepage: https://ojs.unikom.ac.id/index.php/injuratech

[16] Lerch, C., \& Gotsch, M. (2015). Digitalized product-service systems in manufacturing firms: A case study analysis. Research Technology Management, 58(5), 45-52.

[17] Mezger, F. (2014). Toward a capability-based conceptualization of business model innovation: Insights from an explorative study. $R$ and D Management, 44(5), 429-449.

[18] Brennen, J.S. and Kreiss, D. (2016). Digitalization. In The International Encyclopedia of Communication Theory and Philosophy,Wiley-Blackwell, Chichester (pp. 556-566).

[19] Matzler, K., Bailom, F., von den Eichen, S. F., \& Kohler, T. (2013). Business model innovation: Coffee triumphs for Nespresso. Journal of Business Strategy, 34(2), 30-37.

[20] Kiel, D., Arnold, C., Collisi, M., \& Voigt, K. I. (2016). The impact of the industrial internet of things on established business models. IAMOT 2016 - 25th International Association for Management of Technology Conference, Proceedings: Technology - Future Thinking, July, 673-695.

[21] Coupette, J. (2015). Digitalisierung zwischen Erwartung und Implementierung. IM+io Fachzeitschrift Fur Innovation, Organisation Und Management, 1, 69-75

[22] Finance.detik.com

[23] Pontianak Tribune Journalist, 2016

[24] Christopher, M., \& Towill, D. R. (2010). Developing Market Specific Suppyl Chain. The International of Logistics Management, 13(1), 1-16.

[25] Adim, C.V., Lebura, S., \& Adubasim, E.I. (2017). Innovation culture and organization in hospitality firms in Port Harcourt. Nigerian Business and Social Riview, 9(1), 66-79.

[26] Weber, M. A., Schiffrin, E. L., White, W. B., Mann, S., Lindholm, L. H., Kenerson, J. G., Flack, J. M., Carter, B. L., Materson, B. J., Ram, C. V. S., Cohen, D. L., Cadet, J. C., JeanCharles, R. R., Taler, S., Kountz, D., Townsend, R., Chalmers, J., Ramirez, A. J., Bakris, G. L., ... Harrap, S. B. (2014). Clinical practice guidelines for the management of hypertension in the community a statement by the american society of hypertension and the international society of hypertension. Journal of Hypertension, 32(1), 3-15.

[27] McKinsey \& Company. (2001). The war on talent. McKinsey \& Company Inc.

[28] Worldwide Quality Assurance (APAC). (n.d.). No Title. Email: Jakarta@wqa-Sea.Com. www.wqa-apac.com

[29] Wynn-Williams, K. L. H. (2005). Performance assessment and benchmarking in the public sector: An example from New Zealand. Benchmarking, 12(5), 482-492. https://doi.org/10.1108/14635770510619393

[30] Chiu, V., Liu, Q., Muehlmann, B., \&..Baldwin, A. A. (2019). A bibliometric analysis of accounting information systems journals and their emerging technologies contributions. International Journal of Accounting Information Systems, 32(November), 2443. https:// doi.org/10.1016/j.accinf.2018.11.003

[31] Kocsis, D. (2019). A conceptual foundation of design and implementation research in accounting information systems. International Journal of Accounting Information Systems, 34, 100420. https://doi.org/10.1016/j.accinf.2019.06.003

[32] Appelbaum, D., Kogan, A., Vasarhelyi, M., \& Yan, Z. (2017). Impact of business analytics and enterprise systems on managerial accounting. International Journal of Accounting Information Systems, 25(April), 29-44. https://doi.org/10.1016/j.accinf.2017.03.003

[33] Meiranto, W., Widiastuti, K., \& Puspitasari, E. (2013). Peran Karakteristik Sistem Akuntansi Manajemen Sebagai Variabel Yang Memediasi Pengaruh Teknologi Informasi Dan Saling Ketergantungan Terhadap Kinerja Manajerial (Studi Pada PD BPR BKK se-Jawa Tengah). Dinamika Akuntansi, Keuangan Dan Perbankan, 2(1), 1-13. 
International Journal of Research and Applied Technology

$$
\text { 2(1)(2022) 11-29 }
$$

Journal homepage: https://ojs.unikom.ac.id/index.php/injuratech

[34] Mia, L., \& Chenhall, R. H. (1994). The usefulness of management accounting systems, functional differentiation and managerial effectiveness. Accounting, Organizations and Society, 19(1), 1-13.

[35] Gordon, L. A., \& Narayanan, V. K. (1984). Management accounting systems, perceived environmental uncertainty and organization structure: An empirical investigation. Accounting, Organizations and Society, 9(1), 33-47. https://doi.org/10.1016/03613682(84)90028-X

[36] Kompas.com 2016.

[37] Jensen, M., C., dan W. Meckling, 1976. "Theory of the firm: Managerial behavior, agency cost and ownership structure", Journal of Finance Economic 3:305- 360, diakses dari: http:// www.nhh.no/for/courses/spring/eco420/jensenmeckling-76.pdf.

[38] Unruh, G., Kiron, D. (2017). Digital transformation on purpose. MIT Sloan Management Review, 6.

[39] Westerman, G., Calméjane, C., Bonnet, D., Ferraris, P., \& McAfee, A. (2011). Digital Transformation: A roadmap for billion-dollar organizations. MIT Center for Digital Business and Capgemini Consulting, 1, 1-68.

[40] Bloching, B., Leutiger, P., Oltmanns, T., Rossbach, C., Schlick, T., Remane, G., ... \& Shafranyuk, O. (2015). Die digitale Transformation der Industrie. Was sie bedeutet. Wer gewinnt. Roland Berger Strategy Consultants and BDI, Munich, Berlin, February.

[41] Linz, C., Müller-Stewens, G., \& Zimmermann, A. (2017). Radical business model transformation: Gaining the competitive edge in a disruptive world. Kogan Page Publishers.

[42] Kagermann, H., Wahlster, W., \& Helbig, J. (2013). Recommendations for implementing the strategic initiative Industrie 4.0: Final report of the Industrie 4.0 Working Group. Forschungsunion: Berlin, Germany.

[43] Porter, M.E., and Heppelman, J.. (2015). How Smart, Connected Products Are Trannsforming Companies. Harvard Business Review, 93(10), 96-114.

[44] Mehrabi, S., Siyadat, S., \& Allameh, S. (2013). Examining the degree of organizational agility from employees' Perspective (Agriculture-Jahad Organization of Shahrekord City). International Journal of Academic Research in Business and Social Sciences, 3(5), 315323.

[45] Wyman-Oliver. (2018). Financial Deepening in Indonesia.Funding Infastructure Development Catalyzing Economic Growth. Mandiri Institute.

[46] Thomas, J. B., Clark, S. M., \& Gioia, D. A. (1993). Strategic sensemaking and organizational performance: Linkages among scanning ... Management, 36(2), 239-270. http:// www.ncbi.nlm.nih.gov/pubmed/10125120

[47] Abdul Halim. 2009. Akuntansi sector Publik Akuntansi Keuangan Daerah, Edisi Pertama. Jakarta: Salemba Empat

[48] Slavković, M., \& Babić, V. (2013). Knowledge management, innovativeness, and organizational performance: Evidence from Serbia. Economic Annals, 58(199), 85-108.

[49] Chenhall, R. H. (2018). Management control systems design within its organizational context: findings from contingency-based research and directions for the future. Accounting, Organizations and Society, 89(4), 127-168.

[50] Hariyati, Tjahjadi, B., \& Soewarno, N. (2019). The mediating effect of intellectual capital, management accounting information systems, internal process performance, and customer performance. International Journal of Productivity and Performance Management, 68(7), 1250-1271. 
International Journal of Research and Applied Technology

$$
\text { 2(1)(2022) 11-29 }
$$

Journal homepage: https://ojs.unikom.ac.id/index.php/injuratech

[51] Ong, C. S., \& Chen, P. Y. (2014). The effects of IT: From performance to value. Industrial Management and Data Systems, 114(1), 70-85.

[52] Chen, Y., Wang, Y., Nevo, S., Benitez, J., \& Kou, G. (2017). Improving strategic flexibility with information technologies: Insights for firm performance in an emerging economy. Journal of Information Technology, 32(1), 10-25. https:/ / doi.org/10.1057/jit.2015.26

[53] Gligor, D. M., Esmark, C. L., \& Holcomb, M. C. (2015). Performance outcomes of supply chain agility: When should you be agile? Journal of Operations Management, 33-34, 7182.

[54] Mukesh Kumar, Sandeep Singh, and Santanu Kumar Rath(2015). Classification of microarray data using functional link neural network. Procedia Computer Science, 57:727-737

[55] Ayu, G., \& Dahen, L. D. (2015). Pengaruh Karakteristik Informasi Sistem Akuntansi Manajemen Terhadap Kinerja Manajerial Studi Empiris Pada Pt Bank Perkreditan Rakyat Di Kabupaten Tanah Datar. Economica, 3(1), 89-94.

[56] Chia, Y. M. (1995). Decentralization, Management Accounting System (Mas) Information Characteristics and Their Interaction Effects on Managerial Performance: a Singapore Study. Journal of Business Finance \& Accounting, 22(6), 811-830.

[57] Wadan, R., Teuteberg, F., Bensberg, F., \& Buscher, G. (2019). Understanding the Changing Role of the Management Accountant in the Age of Industry 4.0 in Germany. Proceedings of the 52nd Hawaii International Conference on System Sciences, 5817-5826.

[58] Aguinis, H., Cascio, W. F., \& Ramani, R. S. (2017). Science's reproducibility and replicability crisis: International business is not immune. Journal of International Business Studies, 48(6), 653-663.

[59] Ekweli, F., \& Hamilton, P. D. I. (2020). Product Innovation And Organizational Agility In The Banking Sector Of Nigerian Economy. Global Scientific Journal, 8(1)

[60] Soobaroyen, T., \& Poorundersing, B. (2008). The effectiveness of management accounting systems: Evidence from functional managers in a developing country. In Managerial Auditing Journal (Vol. 23, Issue 2).

[61] Pedroso, E., Gomes, C. F., \& Yasin, M. M. (2020). Management accounting systems: an organizational competitive performance perspective. Management Accounting Systems, $27(6), 1843-1874$.

[62] Hutahayan, B. (2020). The mediating role of human capital and management accounting information system in the relationship between innovation strategy and internal process performance and the impact on corporate financial performance. Benchmarking, 27(4), 1289-1318. https:// doi.org/10.1108/BIJ-02-2018-0034

[63] Sekaran, Uma., dan R. B. (2017). Metode Penelitian Untuk Bisnis : Pendekatan Pengembangan Keahlian (6th ed.). Salemba Empat.

[64] Arifin, Z. (2014). Penelitian Pendidikan: Metode dan Paradigma Baru. PT Remaja Rosdakarya

[65] Sugiyono. (2017). Metode Penelitian Kuantitatif, Kualitatif, dan R\&D. Bandung: Alfabeta, $\mathrm{CV}$

[66] Hair, Jr., et, al. (2010). Multivariate Data Analysis (7th ed.). United States: Pearson.

[67] Ghazali dan Latan. (2015). Structural Equation Modelling Alternative Method With Partial Last Squere. BP Diponegoro University. 
International Journal of Research and Applied Technology

2(1)(2022) 11-29

Journal homepage: https://ojs.unikom.ac.id/index.php/injuratech

[68] Kim, W., Kim, H., \& Hwang, J. (2020). Sustainable growth for the self-employed in the retail industry based on customer equity, customer satisfaction, and loyalty. Journal of Retailing and Consumer Services, 53(February 2019), 101963.

[69] Wadan, R., Teuteberg, F., Bensberg, F., \& Buscher, G. (2019). Understanding the Changing Role of the Management Accountant in the Age of Industry 4.0 in Germany. Proceedings of the 52nd Hawaii International Conference on System Sciences, 5817-5826.

[70] Ismail,Fajri.2018.Statistika untuk Penelitian Pendidikan dan Ilmu-ilmu Sosial, Jakarta : Prenadamedia Group. 